\title{
THE EFFECTS OF DIFFERENT HOUSING TECHNOLOGIES ON WELFARE OF PIGLETS IN REARING **
}

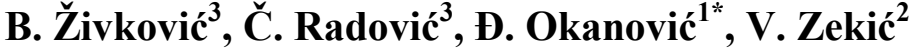 \\ ${ }^{1}$ Research Institute of food technology, Novi Sad, Serbia \\ ${ }^{2}$ Faculty of Agriculture, Novi Sad, Serbia \\ ${ }^{3}$ Institute for Animal Husbandry, Belgrade-Zemun; Serbia \\ *Corresponding author: okanovic@uns.ns.ac.yu \\ ** Original scientific paper. Research financed by the Ministry of Science of Republic of \\ Serbia, project BTN - 351008B
}

\begin{abstract}
During two consecutive years the effects of introduction of new technology i.e. boxes of new dimensions in rearing of piglets compared to conventional type of boxes, on animal welfare through production results were investigated and economical parameters relating to introduction of investigated technology in rearing piglets.

Research was carried out on experimental pig farm of the Institute for Animal Husbandry, Belgrade-Zemun, Serbia. Obtained results demonstrated that introduction of new box, with 14 instead of 6 heads per box, influenced increase in gain by $7,9 \%$, higher feed consumption by $6,7 \%$ and better feed conversion by $0,9 \%$ compared to production results in control group housed in conventional cages. In the structure of expenses, due to higher share of cost of material in total costs, also relative equal reduction of share of labour and depreciation costs for buildings and equipment, but also regardless of that, since cost of material is directly correlated to the production value, mentioned change can be characterized as positive, therefore by application of the new technology of piglet housing the amount of total cost decreased by over $7 \%$, and in general total positive financial effect of $10,6 \%$ can be considered as very satisfactory.

In general, obtained results showed that by application of new technology of piglet housing positive effects are achieved in regard to production and financial results, and also to welfare of this category of pigs.
\end{abstract}

Key words: technological housing systems, weaned piglets 


\section{Introduction}

Optimal pig production is objective of all producers. The most important cause of poor production and animal welfare is disease. The way the piglets are weaned can eliminate the infectious agents, change the growth rate and increase the share of meat in carcass sides at slaughtering.

Long-term study of production results of piglets reared on Experimental pig farm of the Institute for Animal Husbandry, Belgrade-Zemun indicated certain good sides and some disadvantages in production conditions relating to exploitation of the facility and practical production. In the literature (Živković et al., 1978, Stanković et al., 1988; Krivec, 1983; Stanković et al., 1987) certain advantages and disadvantages of individual technological concepts are presented, i.e. results obtained in practice - in pig production.

Objective of this paper was to compare and study production results, economical indicators and welfare of weaned piglets reared during two consecutive years using different technological procedures.

\section{Material and methods}

Investigations were carried out on Experimental pig farm of the Institute for Animal Husbandry, Belgrade-Zemun. Trial included total of 102 weaned piglets reared during 2005 using old rearing technology and during 2006 in new cages for piglets.

Concept of the old rearing/housing technology included production of weaned piglets with 6 animals in single cage above the slurry channel. Dimensions of this cage were following: length and width 1,25 meters, height of the cage was $40 \mathrm{~cm}$ above the floor, and on the top of the cage wire was placed of $20 \mathrm{~cm}$ width. There were six feeding places in the box.

In the second investigation year, new boxes were placed above the old slurry pool, so instead of two conventional cages, there was only one of following dimensions: length 2,40 meters, width 1,25 meters and height of even $75 \mathrm{~cm}$, which is the greatest difference in housing of animals in the trial. There is feeder in the box with 7 feeding places with possibility to add another feeder with six feeding places in the period immediately after and in first 10 days subsequent to weaning, and later added feeder can be removed and placed in cages where younger piglets prior to weaning are housed.

The following parameters/indicators were used for evaluation of obtained results: body mass of piglets at the beginning and end of the trial, 
average body gain of piglets, feed consumption and conversion in animals, as well as structure of expenses and differences in economical indicators in animals compared in the trial.

Obtained results relating to gain were processed statistically by variance analysis and differences between average values by t-test.

\section{Results and Discussion}

In the rearing period, during approx. 47,4 and 48,5 feeding days, piglets of the control housed using the old technological concept, realized average daily gain of 305 grams. Introduction of new technological type of box for piglet rearing, in the second group of animals enabled improvement of the growth rate in average by 24 or $7,87 \%$ in comparison to control group of animals. Nutrition of piglets in boxes of the new type resulted in increase of feed consumption in average by $0,045 \mathrm{~kg}$ or $6,73 \%$ compared to animals reared in the old type of boxes. For achieving $1 \mathrm{~kg}$ of body growth of piglets reared in new type of boxes it took $0,02 \mathrm{~kg}$ or $0,91 \%$ less food compared to the first - control group of piglets reared in old type of boxes (tab. 1).

Table 1. Performance of weaned piglets in the experiments

\begin{tabular}{|l|c|c|}
\hline \multicolumn{1}{|c|}{ Wroup } & $\begin{array}{c}1^{*} \\
\text { Control }\end{array}$ & $\begin{array}{c}2^{* *} \\
\text { Exp. }\end{array}$ \\
\hline \multicolumn{2}{|c|}{ Weaned piglets } \\
\hline The classical old technology of weaned piglets & + & - \\
\hline The new technology of the weaned piglets & - & + \\
\hline Number of piglets in the experiment & 48 & 54 \\
\hline Body mass of weaned piglets at the beginning of the experiment, kg & 9,14 & 8,12 \\
\hline Body mass of piglets at the end of the experiment, kg & 23,60 & 24,04 \\
\hline Duration of the experiment, days & 47,4 & 48,5 \\
\hline Average daily gain, grams & 305 & 329 \\
\hline Compared to the control group, \% & - & $+7,87$ \\
\hline Average daily feed consumption, kg & 0,669 & 0,714 \\
\hline Compared to the control group, \% & - & $+6,73$ \\
\hline Feed conversion ratio, kg & 2,19 & 2,17 \\
\hline Compared to the control group, \% & - & $+0,91$ \\
\hline$*$ *) Old rearing technology includes 6 heads per cage and feeding place for each head \\
$*^{* *}$ ) - New rearing technology includes cage with 14 piglets/cage and 7 feeding places \\
\hline
\end{tabular}

In regard to differences in structure of expenses between observed technologies, the most obvious one is in the share of cost of material in total 
costs. This difference was realized based on relatively equal decrease of cost of labour and cost of depreciation of facility and equipment. Differences in the structure of expenses do not imply directly that there was a change in financial results. Regardless of that, future cost of material is directly related to production value, and stated change can be characterized as positive (tab. 2).

Table 2. The structure of the costs in the experiment at weaned piglets

\begin{tabular}{|c|c|c|}
\hline Group & $\begin{array}{c}1^{*} \\
\text { control }\end{array}$ & $\begin{array}{c}2^{* *} \\
\text { experimental }\end{array}$ \\
\hline \multicolumn{3}{|l|}{ Weaned piglets } \\
\hline The classical old technology of weaned piglets & + & - \\
\hline The new technology of the weaned piglets & - & + \\
\hline The costs of the depreciation, $\%$ & 56,0 & 64,0 \\
\hline The costs of the salaries & 19,0 & 16,0 \\
\hline The depreciation of the facilities and equipment & 25,0 & 21,0 \\
\hline Total costs, $\%$ & 100,0 & 100,0 \\
\hline
\end{tabular}

*) - The classical old technology of the weaned piglets containing 6 heads per the one box

**) - The new technology of weaned piglets containing 14 heads per the one box.

Table 3. The differences in economic items in the experiment at weaned piglets

\begin{tabular}{|l|c|c|}
\hline \multicolumn{1}{|c|}{ Group } & $\begin{array}{c}1^{*} \\
\text { control }\end{array}$ & $\begin{array}{c}2^{* *} \\
\text { experimental }\end{array}$ \\
\hline \multicolumn{2}{|c|}{ Weaned piglets } \\
\hline The classical old technology of weaned piglets & - \\
\hline The new technology of the weaned piglets & + \\
\hline The costs of the material & & 5,89 \\
\hline The costs of the salaries & & -22.24 \\
\hline The depreciation of the facilities and equipment & & $-24,68$ \\
\hline Total costs, \% & & $-7,14$ \\
\hline Income \% & & 1,86 \\
\hline Financial result, \% & 10,63 \\
\hline
\end{tabular}

*) The classical old technology of the weaned piglets containing 6 heads per the one box

**) The new technology of weaned piglets containing 14 heads per the one box.

Direct insight into economical results is possible through analysis of total economical results of the new technology. As presented in table 3, absolute growth/increase was recorded only for cost of material, whereas cost of labour and depreciation of facility and equipment are decreasing. In 
accordance with this the amount of total costs was reduced by over $7 \%$. If we consider also realized increase of income we can conclude that total financial results of $10,63 \%$ was realized which can be interpreted as very satisfactory.

In Canada, in order to improve the pig welfare, so called »separated « early weaning of piglets is applied aiming to control and eradicate disease and in this way improve their production results. According to this system, subsequent to weaning, piglets are isolated from sows and other pig categories (Robert et al., 1999), and this technological operation is a complex of procedures in pig production widely applied in Canada since the beginning of nineties of the last century (Whiting, 2001), so in future, it is necessary to pay more attention to professional participation of pig producers in this so far still unknown procedure in production of weaned piglets (Hurnik, 2007). Special attention should be directed to technological systems of piglet rearing (Stanković et al., 1987), and even more to number of animals in box i.e. to maximal number of piglets per feeding place which Weber et al. (2002) suggested should be less than 10:1, normally taking into consideration that number of animals in box should be max. 40 .

Transportation of pigs is also considered as one of factors influencing not only animal welfare but also economical interest because of potential losses during transport which is common interest of producer and transportation firm (Pasille et al., 2007), so by improvement of transportation equipment potentially negative effects on quality of meat can be reduced but not eliminated (Scott and Schaefer, 2007).

\section{Conclusion}

During two consecutive years the effects of introduction of new technology i.e. boxes of new dimensions in piglet rearing compared to conventional old box type on animal welfare through production results and economical indicators were investigated.

Obtained results showed that introduction of new box with 14 instead of 6 heads per box, had the following effects:

- Better gain by $7,9 \%$, higher feed consumption by $6,7 \%$ and better feed conversion by $0,9 \%$ compared to production results in control group reared in conventional cages. 
- In the structure of expenses, share of cost of material in total costs was higher, due to relatively equal decrease of share of costs of labour and depreciation of facility and equipment.

- Regardless of that, future cost of material is directly correlated to production value and therefore this change can be characterized as positive.

- By application of new technology of piglet housing the amount of total costs was reduced by over $7 \%$,

- Achieved total positive financial results of $10,6 \%$ can be interpreted as very satisfactory.

In general, obtained results showed that by application of new technology of piglet housing positive effects are achieved in regard to production and financial results, and also to welfare of this category of pigs.

\section{EFEKTI RAZLIČITIH TEHNOLOGIJA DRŽANJA NA DOBROBIT PRASADI U ODGOJU}

B. Živković, Č. Radović, Đ. Okanović, V. Zekić,

\section{Rezime}

Tokom dve uzastopne godine istraživani su efekti uvođenja nove tehnologije odnosno boksa novih dimenzija u odgoju prasadi u poređenju sa klasičnim starim tipom boksa, na dobrobit životinja preko proizvodnih rezultata i ekonomske pokazatelje uvođenje ispitivane tehnologije kod prasadi u odgoju. Istraživanja su izvedena na eksperimentalnoj farmi svinja Instituta za stočarstvo, Beograd-Zemun u Srbiji. Dobijeni rezultati su pokazali da je uvođenje novog boksa, sa 14 u odnosu na 6 grla u boksu, imalo efekte izražene boljim prirastom za $7,9 \%$, većom konzumacjom hrane za $6,7 \%$ i povoljnijom konverzijom hrane za $0,9 \%$ u poređenju proizvodnim rezultatima kod kontrolne grupe držane u klasičnim kavezima. U strukturi trškova većim udelom troškova materijala u ukupnim troškovima, zbog relativno ravnomernog smanjenja udela troškova zarada i troškova amortizacije objekata i opreme, i bez obzira na to, budući da utrošak materijala ima direktnu korelaciju sa vrednosti proizvodnje navedenu 
promenu je moguće okarakterisati kao pozitivnu tako da se primenom nove tehnologije držanja prasadi iznos ukupnih troškova smanjio za preko $7 \%$, te se u celini ostvareni ukupan pozitivan finansijski rezultat od 10,6\% može tumačiti kao veoma zadovoljavajući,

U celini dobijeni rezultati su pokazali da se primenom nove tehnologije držanja prasadi $u$ odgoju ostvaruju pozitivni efekti na proizvodne i finansijske rezultate a time i na dobrobit kod ove kategorije svinja.

\section{References}

ANDRIĆ J. (1998): “Troškovi i kalkulacije u poljoprivrednoj proizvodnji”, Poljoprivredni fakultet - Zemun, Beograd

HURNIK J.F. (2007): Look into the future of animal welfare in Canada. The Lennoxvill Symposium Farm Animal Welfare in Canada. New Technologies, Research and Word Trade, $7-8$.

KRIVEC L. (1983): Tehnologija i tehnološko-tehnička rešenja u svinjogojstvu. Svinjarstvo u SR Sloveniji. Sastanak stručnog odbora svinjarstva, Ljubljana, Beograd.

MARKO J., JOVANOVIĆ M., TICA N. (1998): "Kalkulacije u proljoprivredi", Poljoprivredni fakultet, Novi Sad

PASILlE de A.M., MORTEAU A., DOONAN G. (2007): Farm animal transport regulations in Canada and abroad. The Lennoxville Symposium Farm Animal Welfare in Canada. New Technologies, Research and Word Trade, $2-3$.

ROBERT S., WEARY D., GONOYOU H. (1999): Segregated early weaning and welfare of piglets. Journal of Applied Animal Welfare Science, Vol. 2, $\mathrm{N}^{\mathrm{o}} 1,31-40$.

SCOTT S., SCHAEFER A. (2007): The effect of transport on animal welfare and meat quality. The Lennoxville Symposium Farm Animal Welfare in Canada. New Technologies, Research and Word Trade, 6.

STANKOVIĆ M., ANASTASIJEVIĆ V., NIKOLIĆ P. (1988): Savremeno gajenje svinja, Nolit.

STANKOVIĆ M., STEVANOVIĆ M., MARKOVIĆ Z., GLUHOVIĆ M., ŽIVKOVIĆ B. (1989): Komparativna istraživanja kvaliteta ambijenta dva tehnološk sistema u proizvodnji svinja (tunelski i "all in - all out") i rezultati odgoja prasadi. Zbornik radova Instituta za stočarstvo, Beograd-Zemun Polje, 1-2, 47-55.

ZEKIĆ V., OKANOVIĆ Đ., ŽIVKOVIĆ B. (2006): Ekonomski aspekti proizvodnje svinjskog mesa. Zbornik kratkih sadržaja, Herceg Novi, 18-25 
jun, Poljoprivredni fakultet, Novi Sad, 2006, str. 29.

ŽIVKOVIĆ S. (1978): Ishrana svinja, Novi Sad.

WEBER R., KIRCHER A., WECHSLER B. (2002): How welfare - oriented are mash tube feeders in weaner rearing. Landtechnik - Net, p. 2.

WHITING T. (2001): Isolated Weaning Technology: Incorporation into the Canadian Code of Practice Pigs. American Society and Biological Engineers, 1. 